\title{
ДІЯЛЬНІСТЬ ТАЕМНИХ ПОЛЬСЬКИХ ШКІЛ У КИЇВСЬКІЙ ГУБЕРНІЇ (ОСТАННЯ ТРЕТИНА ХІХ - ПОЧАТОК ХХ СТОЛІТТЯ)
}

Анотація: У статті аналізується стан освіти польської шляхти Київської губернії в умовах русифікації та поступової інтеграції Правобережної України до імперських структур в останній третині XIX - на початку XX ст. Польська освіта у цей період виступала не лише основним фактором опору проти царського уряду, а й сприяла націоналізації свідомості поляків. $B$ умовах відсутності можливостей легально розвивати польські освітні осередки, почали з'являтися таємні школи з метою збереження власної національно-культурної ідентичності.

Ключові слова: освіта, таємні школи, польська шляхта, Київська губернія, інтеграційна політика, русифікащія

3 1860-х рр. і до початку XX ст. стратегічний напрямок царського уряду був спрямований на подальшу інтеграцію Правобережної України до складу Російської імперії. Після придушення Січневого повстання 1863-1864 рр. почався посилений наступ російського царизму на польську освіту. Польські школи підлягали закриттю, і тому польська освіта фактично втратила офіційний статус.

Однак, повністю ліквідувати репресивними заходами багатовікові традиції польського шкільництва уряду все ж таки не вдалося. Почали з'являтися таємні школи та приватні пансіони, які здебільшого утримувалися за кошти польської знаті та Римокатолицької церкви. У згаданих школах, в основному, навчалися діти польської шляхти, поміщиків, міщан і селян, але й траплялися випадки, коли у школах навчалися діти православного віросповідання'.

Аналіз історіографії свідчить про постійний тиск російського уряду на польську шляхту, який здійснювався як в соціально-економічній, так і в освітньо-культурній сферах суспільного життя. Надважливою у цих процесах була польська система освіти на Правобережній Україні, яку царизм прагнув замінити на російську.

Політика російського царизму щодо польської освіти в регіоні стала предметом

\footnotetext{
• Гончарова Ольга Віталіївна - аспірантка Уманського державного педагогічного університету імені Павла Тичини (Умань, Черкаська область, Україна);

ORCID: https://orcid.org/0000-0001-9449-6091; e-mail: honcharova77789@gmail.com

Кривошея Ігор Іванович - кандидат історичних наук, професор, професор кафедри всесвітньої історії та методик навчання Уманського державного педагогічного університету імені Павла Тичини (Умань, Черкаська область, Україна); ORCID: https://orcid.org/0000-0003-1429-8293; e-mail: igorkryvosheia@gmail.com

${ }^{1}$ Полішук Ю. Політика російського царизму щодо польської освіти в Правобережній Україні (друга половина XIX - початок XX століття). Наукові записки [Інституту політичних і етнонаціональних досліджень ім. І.Ф. Кураса НАН України]. 2008. Вип. 37. С. 157.
} 
дослідження І. Лісевича 2 , О. Буравського ${ }^{3}$, О. Ніколаєнко ${ }^{4}$. На освітні процеси у контексті національної політики царизму звертають увагу Ю. Поліщук ${ }^{5}$ Н. Щербак 6 . Дослідники 0. Міллер ${ }^{7}$ і Л. Горизонтов ${ }^{8}$ проаналізували адміністративні заходи у сфері освіти крізь призму стратегії поступової інтеграції регіону.

Про освіту польських дітей і молоді на Правобережній Україні, обставини залучення польської шляхти до освітньої діяльності писали Л. Заштовт ${ }^{9}$, Д. Бовуа ${ }^{10}$, Т. Епштейн ${ }^{11}$. Аспекти суспільно-культурного розвитку поляків на початку XX ст. на основі опублікованих та архівних матеріалів відтворює М. Коженьовський ${ }^{12}$.

Meта дослідження полягає у тому, щоб проаналізувати діяльність польських таємних освітніх закладів Київської губернії в останній третині XIX - на початку XX ст.

Після 1863 р. царат переглянув кадрову політику у Південно-Західному краї й усіх поляків-католиків було замінено на чиновників православного віросповідання, заборонялася торгівля польськими книгами та викладання польською мовою. До краю прибували російські чиновники, вчителі та православне духовенство. Для заохочення припливу чиновників у 1864 р. було видано указ № 40656 «Об увеличении содержания и выдаче пособий, подъёмных и прогонных денег Русским чиновникам ведомства Министерства Внутренних Дел в Юго-Западном крае», згідно 3 яким надбавка чиновникам зростала до $50 \%{ }^{13}$.

у липні 1864 р. імператором було затверджено «Положення про початкові училища», за яким вводилася єдина система початкової освіти. Шкільні заклади дозволялося відкривати як державним установам і відомствам, так і громадським об'єднанням і навіть приватним особам. Контроль за навчальним процесом і керівництво

\footnotetext{
2 Лісевич I.T. У затінку двоглавого орла (Польська національна меншина на Наддніпрянській Україні в другій половині XIX ст. - на початку XX ст.). Київ: Інститут історії України, 1993. 87 с.; Лісевич I.T. Духовно спраглі (духовне життя польської національної меншини на Наддніпрянській Україні в 1864-1917рр.). Київ, 1997. 240 с. ${ }_{3}^{3}$ Буравський О.А. Поляки Волині у другій половині XIX - на початку XX ст. Житомир: Вид-во ЖДУ, 2004. 168 с.

${ }^{4}$ Ніколаєнко О. Польські жінки Наддніпрянської України в другій половині XIX - на початку XX ст.: громадське і приватне життя: монографія. Харків: Вид-во НТМТ, 2015. 360 с.

${ }^{5}$ Поліщук Ю.М. Національні меншини Правобережжя України у контексті етнічної політики Російської імперії (кінець XVIII - початок XX ст.). Київ: ІПіЕНД ім. І.Ф. Кураса НАН України, 2012. 432 с.

${ }^{6}$ Щербак $H$. Національне питання в політиці царизму у Правобережній Україні (кінець XVIII - початок ХХ ст.). Київ, 2005. 616 с.

${ }^{7}$ Миллер А. Украинский вопрос в Российской империи. Київ: Laurus, 2013. 416 с.

${ }^{8}$ Горизонтов Л.Е. Парадоксы имперской политики: поляки в России и русские в Польше (XIX - начало ХХ вв.). Москва: Индрик, 1999. 272 с.

${ }^{9}$ Zasztowt L. Polskie szkółki ludowe na Ukrainie w latach 1905-1914. Rozprawy z dziejów oświaty. T. XXXIII. 1990. S. 87-105.; Zasztowt L. Europa Środkowo-Wschodnia a Rosja XIX-XX wieku. W kręgu edukacji I polityki. Warszawa, 2007. $543 \mathrm{~s}$.

${ }^{10}$ Beauvois $D$. Rosyjsko-polska wojna o oświatę na terenie Ukrainy (1863-1914). Europa nieprowincjonalna, red. K. Jasiewicz. Warszawa, 1999. $428 \mathrm{~s}$.

${ }^{11}$ Epsztein T. Edukacja domowa dzieci i młodyieży ziemiańskiej na Wołyniu, Podolu i Ukrainie w latach 1864-1914. Nauczanie domowe dzieci polskich od XVIII do XX wieku. Zbiór studiów. Pod red. K. Jakubiaka i A. Winiarza. Bydgoszcz, 2004. S. 331-342.

${ }^{12}$ Коженьовський М. За Золотими ворітьми. Суспільно-культурна діяльність поляків у Києві в 1905-1920 роках [пер. А. Павлишин; наук. ред. Н. Риндюк]. Київ, 2015. 654 с.

${ }^{13}$ Полное собрание законов Российской империи. Собрание 2-е. СПб: Тип. 2-го Отд-ния Собств. ее императ. величества канцелярии, 1830-1885. Т. 39: 1864. Отд. 1: от №40457-41318. 1867. С. 204.
} 
покладалися на відповідні (губернські, повітові) училищні ради, що складалися 3 чиновників і духовенства. «Положення» передбачало, що губернські училищні ради мали очолити єпархіальні архієреї. Нагляд за релігійно-моральним вихованням учнів і за благонадійністю вчителів здійснювали місцеві священики. Усі школи підпорядковувалися Міністерству народної освіти або Синоду, й у навчальному процесі вони повинні були керуватися підготовленими цими відомствами програмами. Все навчання мало проводитися російською мовою і головним його завданням було «виховувати серед народу релігійність і вірнопідданство» ${ }^{14}$.

У циркулярі київського генерал-губернатора О. Безака від травня 1865 p. вказувалося про закриття приватних шкіл, які утримувалися поляками та викладання в яких велося польською мовою. Документ був розісланий всім губернаторам ${ }^{15}$.

Збереження польської мови залежало від ступеня національної свідомості у родині. Однак, інколи до російської влади проявляли лояльність. Графиня Браницька з Білої Церкви призначила суму в розмірі 287 тис. рублів на народні школи, тобто на русифікацію українського селянства та сприяла русифікації гімназії у Білій Церкві після 1861 р. Зі спогадів Е. Бжезинського, який навчався там з 1866 по 1872 рр., можна стверджувати, що навчальний заклад носив двоїстий характер. Приватний заклад дозволяв приймати до 80\% польських учнів, де за ними слідкував сам генералгубернатор, відвідуючи гімназію16.

Ще до 1863 р. двоє студентів Київського університету організували таємну школу: А. Мйодушевський у маєтках Браницьких в Ставищі й околиці та К. Гонсьоровський в околицях Тетіїва. Шляхетські маєтки не боялися загрози конфлікту з російською владою. Один з таких маєтків належав Пржеџлавським у Любечі на Київщині, де школа для польських дітей існувала понад десяток років під виглядом викладання ремесла. Менше пощастило К. Крижановському з Радомишля. За навчання дітей у своєму будинку його було ув'язнено, а коли на сторінках газети «Dziennik Kijowski» 3'явилася стаття про захист пана Кипряна, через декілька годин після випуску номера видавців газети Т. Міхаловського та А. Червінського було ув'язнено на Лук'янівцях за рішенням генерал-губернатора Трепова. У Бердичівському повіті в маєтку Половецьких капітан $Є$. Соколовський з двома дочками протягом десяти років, починаючи з 1873 р., керували таємними школами у своєму маєтку та сусідніх селах ${ }^{17}$.

Суттєве значення для розвитку національної самосвідомості, плекання мови, процесу виховання дітей і молоді мала домашня освіта, яка привносила те, чого не давала російська школа.

Домашня освіта була підготовкою до школи. Початковий етап домашнього навчання складався з вивчення іноземних мов. Хлопчиків і дівчаток розділяли, і ті мали окремих вчителів. У віці 4-5 років діти шляхти вивчали французьку мову як мову всієї освіченої європейської еліти. Здебільшого, хлопчики вивчали ще німецьку, а дівчата -

\footnotetext{
${ }^{14}$ Полішук Ю. Політика російського царизму щодо польської освіти в Правобережній Україні (друга половина XIX - початок XX ст.). Наукові записки Інституту політичних і етнонаціональних досліджень ім. І.Ф. Кураса НАН Украӥни. 2010. Вип. 3. С. 158.

${ }^{15}$ Державний архів Київської області (далі - ДАКО). Ф. 2. Оп. 74. Спр. 108. Арк. 1.

${ }^{16}$ Бовуа Д. Трикутник Правобережжя. Царат, шляхта і народ. 1793-1914 рр. Кліо, 2020. С. 816-817.

${ }^{17}$ Kornecki J. Oświata polska na Rusi w czasie wielkiej wojny. Z przedmową Stanisława Zielińskiego. Warszawa: Druk. Społeczna, 1937. C. 6.
} 
англійську, також дітей навчали української та російської. У програмі освіти дівчаток була наука управління господарством. Вони вишивали, малювали картини, робили композиції з букетів. Хлопці креслили, малювали. У віці 7-8 років діти відвідували лекції. Був обов'язковий шкільний режим, опитування, перевірка домашнього завдання та випускні іспити. Програма навчання старших дітей була скерована на лінгвістичну освіту, проводились лекції з історії та історії літератури, вивчалася латинська та грецька мови, каліграфія, музика, хлопчиків навчали російської мови тощо ${ }^{18}$.

Ще в середині XIX ст. важливим питанням стала можливість доступу жінок до освіти. Отримання освіти нарівні з чоловіками відкривало шлях для працевлаштування. У 70-х рр. XIX ст. в Російській імперії було проведено освітню реформу, спрямовану на розширення мережі середніх навчальних закладів для дівчат. 3 цього часу зростає кількість гімназій, прогімназій, народних училищ. Однак, польське населення ПівденноЗахідного краю шукало можливість надати дівчатам освіту в недержавних закладах.

Для хлопців, яким диплом про закінчення гімназії був потрібен для вступу в університети, альтернативи навчанню у російських навчальних закладах не було. Одночасно польські дівчата робили ставку на приватне навчання ${ }^{19}$. Як зазначає Т. Епштейн: «Не можна було й помислити, щоб панянка могла навчатися в російській школі. Вони цілковито бойкотувалися ${ }^{20}$.

Через нелегальний статус пансіони мали можливість самі затверджувати програму навчання. У приватних пансіонах дівчат навчали польській, французькій, німецькій мовам, музиці, малюнку, рукоділлю, закону Божому. Закон Божий, як правило, викладав місцевий ксьондз, якого запрошували для навчання дівчат. Рукоділля було обов'язковим елементом жіночої освіти ${ }^{21}$.

Як бачимо, у програмі навчання відсутні точні та природничі науки. Фактично названі предмети готували дівчину до приватного життя, де б вона виконувала функції домогосподарки, а також прикрашала б вітальню, виявивши знання іноземних мов i розважаючи гостей грою на музичному інструменті. У польських жіночих пансіонах гуманітарний напрямок спричинений їх нелегальністю. На відміну від державних закладів, у програмі таємних пансіонів були відсутні такі дисципліни як історія чи географія, що можна пояснити невдоволеністю польським населенням існуючими кордонами та тогочасною інтерпретацією історичних подій. Якщо офіційно працюючі пансіони могли видавати свідоцтва на право викладання у приватних домах своїм випускницям і забезпечувати офіційним працевлаштуванням, то, звичайно, про це не йшлося у таємних пансіонах 22 .

Вибір пансіону, як освітнього закладу для дівчини, означав збереження нею

\footnotetext{
${ }^{18}$ Epsztein T. Edukacja domowa dzieci i młodyieży ziemiańskiej na Wołyniu, Podolu i Ukrainie w latach 1864-1914. Nauczanie domowe dzieci polskich od XVIII do XX wieku. Zbiór studiów. Pod red. K. Jakubiaka i A. Winiarza. Bydgoszcz, 2004. S. 333-335.

${ }^{19}$ Ніколаєнко О. Польська пансіонна жіноча освіта на Правобережжі наприкінці XIX ст. «Історичні регіони Украӥни: минуле та сучасність»: матеріали Всеукраїнської наукової конференщії. Харків, 2013. С. 81.

${ }^{20}$ Epsztein T. Edukacja dzieci i mlodzieży w polskich rodzinach ziemiańskich na Wołyniu, Podolu i Ukrainie w II połowie XIX wieku. Warszawa: DiG, 1998. S. 53.

${ }^{21}$ Аніщенко О. Фахова підготовка дівчат у дитячих притулках (1839-1911). Шлях освіти. 2000. № 1. С. 40-42.

${ }^{22}$ Ніколаєнко 0. Польські жінки Наддніпрянської України в другій половині XIX - на початку XX ст.: громадське і приватне життя: дис... канд. іст. наук: 07.00.01 - історія України. Харківський національний університет імені В.Н. Каразіна. Харків, 2017. С. 129.
} 
національної ідентичності, але при цьому обмежував можливості працевлаштування у майбутньому. Фактично таку освіту обирали для своїх доньок заможні верстви польського населення. Однак, з другої половини XIX ст. пансіони існують у меншій кількості, це пов'язано з виникненням гімназій, прогімназій та училищ, крім того, пансіони почали перетворюватися на приватні гімназії.

У жовтні 1886 р. в с. Зелений Ріг Уманського повіту було викрито таємний польськопатріотичний жіночий пансіон, який існував біля п'ятнадцяти років. Знаходився на утриманні дворянки Л. Пшесмицької та передбачав навчання лише дівчат польського походження та католицького віросповідання. Вік учениць становив від 10 до 19 років, кількість дівчат сягала до 26 в рік. Персонал у пансіоні складався 3 жінок, лише Закон Божий викладав місцевий ксьондз. Предмети викладалися польською мовою, частина за паперовими книгами і частина - за рукописними записами, наприклад, 3 історії та географії. У пансіоні вивчали і російську мову за підручниками з граматики Кирпичникова, хрестоматії Галахова. При обшуку було знайдено друковану програму польською мовою Варшавського пансіону Крживодлоцької, якою, ймовірно, керувалася і Пшесмицька. У цій програмі окремо виділена історія Польщі. У пансіоні існував порядок, за яким кожну п'ятницю та неділю діти обов'язково ходили до каплиці, де місцевий ксьондз проголошував проповіді. У 1873 р. Л. Пшесмицька померла і пансіон перейшов до її племінниці. Судові слідчі викривши пансіон, застали в ньому лише 5 дівчаток віком 10-12 років і вчительку, а інші, близько 20 чоловік, розї̈халися влітку по закінченню навчання ${ }^{23}$.

У випадку з міським училищем в Умані, яке утримувала Ц. Кожем'яка, лютеранка за віровизнанням, було виявлено, що лише одна вчителька С. Стефанська є полькою, а не всі вчителі, як зазначалося в анонімному доносі. Училище не закрили, але С. Стефанській заборонили викладання. Були випадки викриття шкіл, де проводилося домашнє виховання. Так, у с. Махновському Бердичівського повіту за доносом було викрито школу, де навчалось 16 дітей-католиків. Перевірка урядника виявила, що це було домашнє навчання у приватному будинку ${ }^{24}$.

Наприкінці XIX - на початку XX ст. поширюється позашкільний освітній рух польської молоді. У пансіонах і гімназіях, де навчалися поляки, функціонували нелегальні гуртки. У них школярі займалися не тільки самоосвітою, але й захоплювалися різноманітними політичними ідеями. Більшість таких таємних організацій були за своїм складом чоловічими. Жителька Бердичева М. Івашкевічова пояснює цей факт тим, що дівчатам у приватних закладах було дозволено говорити польською мовою, коли для хлопців ці таємні гуртки були єдиною можливістю відчути себе поляком у російських навчальних закладах ${ }^{25}$.

Організацією, яка брала участь в інституціалізації таємного польського шкільництва, було Народне коло, засноване 1890 р. членами студентської організації «Корпорація» Г. Сарцевичем і Л. Левковичем. у 1897 р. на базі Народного кола 3

\footnotetext{
${ }^{23}$ Центральний державний історичний архів у м. Києві (далі - ЦДІАК України). Ф. 442. Оп. 836. Спр. 227. Арк. 1-2.

${ }^{24}$ ЦДІАК України. Ф. 707. Оп. 296. Спр. 127. Арк. 32-36, 67-74.

${ }^{25}$ Iwaszkiewiczowa M. Wspomnienia. Biblioteka Zakładu Narodowego im. Ossolińskich we Wrocławiu. Sygn. 13173. S. 123.
} 
ініціативи Ю. Анджейовського і Л. Янковського виникло Коло народної освіти. Метою товариства було надання освітньої допомоги якнайширшим верствам польського населення в Києві 3 наголошуванням передусім на вивченні польської мови, історії Польщі та національної літератури ${ }^{26}$.

Сплеск таємного польського шкільництва припадає на другу половину 1980-х рр. У цей час жандармерією було викрито таємні школи, хоча важко сказати, наскільки відповідали дійсності оприлюднені факти існування таких шкіл. До уваги бралися анонімні повідомлення на вчителів, які нібито займалися нелегальною таємною діяльністю ${ }^{27}$.

У 1886 р. попечитель Київського навчального округу писав до начальника середніх навчальних закладів, що декілька вихованців, будучи незадоволеними наявністю книг в учнівській бібліотеці, заснували «гурток для саморозвитку», де читали книги не затверджені міністерством для учнівських бібліотек і щомісячно вносили по 20 коп. для придбання нових книг ${ }^{28}$.

До 1892 р. ще не потребувалося офіційного дозволу для отримання домашньої освіти, вона була дозволена циркуляром міністра народної освіти від 14 лютого 1882 р. Хоча, на сторінках газети «Киевлянин» за 1884 р. міститься інформація про розкриття 4-х неофіційних польських шкіл. 6 березня 1890 р. генерал-губернатор І. Ігнатьєв прийняв рішення відновити обмеження, застосовані після 1863 р., і заборонив відкривати школи без спеціального дозволу. У випадку першого порушення заборони накладався штраф у сумі 75 рублів, який міг замінитися на 3 тижні арешту, при повторному порушенні покарання подвоювалося. 3 квітня 1893 р. штраф було збільшено до 300 рублів, а арешт до 3-х місяців. Покарання поширювалося як на утримання таємних шкіл, так і на приватні уроки, якщо такі надавалися без дозволу ${ }^{29}$.

у 1894 р. серед вихованців Білоцерківської гімназії було створено гурток саморозвитку польсько-патріотичного спрямування, який мав заборонені книги в бібліотеці ${ }^{30}$.

Революційні події 1905-1907 pp. змусили російський царизм піти на певні політичні, економічні, соціальні та національні поступки. Не стала винятком й освітня сфера. 17 квітня 1905 p. Микола II підписав указ «Про зміцнення початків віротерпимості», який дозволив викладати в школах Закон Божий рідною мовою. 1 травня того ж року оприлюднено закон, який відмінив заборону на навчання дітей польською мовою у світських навчальних закладах. 24 серпня 1906 р. Санкт-Петербург скасував ще один указ від 3 квітня 1892 р. «Про покарання за таємне навчання в західних губерніях імперії», який забороняв відкривати польські школи на Правобережжі України ${ }^{31}$.

У період революційних подій на Правобережній Україні відкривалися приватні польські школи. До шкіл ставилася вимога, щоб навчання проводилося лише для дітей польської національності і предмети, окрім польської мови та Закону Божого,

\footnotetext{
${ }^{26}$ Коженьовський М. За Золотими ворітьми. Суспільно-культурна діяльність поляків у Києві в 1905-1920 роках [пер. А. Павлишин; наук. ред. Н. Риндюк]. Київ, 2015. С. 148.

${ }^{27}$ Zasztowt L. Europa Środkowo-Wschodnia a Rosja XIX-XX w. W kręgu edukacji i polityki. Warszawa, 2007. S. 180.

${ }^{28}$ ЦДІАК України. Ф. 707. Оп. 87. Спр. 6720. Арк. 2.

${ }^{29}$ Бовуа Д. Гордиев узел Российской империи: Власть, шляхта и народ на Правобережной Украине (17931914). Москва: Новое литературное обозрение, 2011. С. 827.

${ }^{30}$ ЦДІАК України. Ф. 707. Оп. 262. Спр. 18. Арк. 1.

${ }^{31}$ Полішук Ю.М. Національні меншини Правобережжя України у контексті етнічної політики Російської імперії (кінець XVIII - початок XX ст.). Київ: ІПіЕНД ім. І.Ф. Кураса НАН України, 2012. С. 220.
} 
викладалися російською мовою, а вивчати польську мову могли лише на факультативах. Однак, такі обмеження часто ігнорувалися. До шкіл приймалися не лише католики, а предмети викладалися польською мовою ${ }^{32}$.

Попри це, місцева влада активно наполягала на відміні урядових послаблень щодо польської освіти та закриття таємних і приватних шкіл продовжувалися.

На початок ХХ ст. є лише довідкові дані по Київській губернії. У 1904 р. тут було 1495 шкіл, у тому числі 1263 церковно-приходських і 232 шкіл Міністерства народної освіти. До 1907 р. кількість шкіл зросла до 1 587. У 1900-1904 рр. у Київській губернії було відкрито 50 нових церковно-приходських шкіл і 72 державних, тобто всього 122 школи. У 1904-1907 рр. було створено ще 92 школи ${ }^{33}$.

У 1905 р. настоятель Уманського римо-католицького парафіяльного костелу ксьондз Карл Закусило був одним із ініціаторів створення у місті «Уманського римокатолицького доброчинного товариства», діяльність якого було узгоджено зі Статутом від 10 червня 1897 p. $^{34}$

Автор допису в газету 3. Скаржинський повідомляв, що це Католицьке товариство доброчинності є лідером серед уманських громадських інститутів 3 погляду активності та результативності праці. Це молода організація, створена в кінці минулого року (1905), нараховувала вже 139 членів. Вона допомагала бідним з Умані й околиць, і виступала посередником у пошуках для них роботи. Допомагала також дітям, навчаючи їх основам ремесла і забезпечувала харчуванням. Цю традиційну діяльність намагалися розвивати. У лютому 1906 р. було подано клопотання до канцелярії губернатора дозволити відкриття притулку для людей похилого віку та дитячі ясла. Губернське керівництво, однак, досі не надало відповіді. Люди похилого віку і діти були позбавленні таким чином опіки. у планах товариства було відкрити школу ремесла й організувати літні табори. Організатор і душа цього товариства - пан Адам Залютинський ${ }^{35}$.

На початку ХХ ст. у місті створювалися польські національні організації: «Уманське польське гімнастичне товариство» (1907), «Уманське польське жіноче коло» (1907-1908), «Польське товариство літніх колоній в Умані» (1913) ${ }^{36}$. У 1913 р. розглядалося питання про реєстрацію Статуту «Польського товариства літніх колоній в м. Умані» ${ }^{37}$.

Високий рівень неписьменності польського населення Правобережжя, спричинений утисками в освіті, викликав стурбованість громадськості. Намагання подолати цю кризову ситуацію можна прослідкувати за матеріалами жандармерії, що постійно викривала польські таємні школи на Правобережжі. За даними польського науковця Л. Заштовта, протягом 1905-1914 рр. у регіоні було викрито 299 початкових

\footnotetext{
32 Лісевич I. Духовно спраглі (духовне життя польської національної меншини на Наддніпрянській Україні в 1864-1917 рр.). Київ, 1997. С. 8.

${ }^{33}$ Zasztowt L. Polskie szkółki ludowe na Ukrainie w latach 1905-1914. Rozprawy z dziejów oświaty. 1990. T. XXXIII. S. 102.

${ }^{34}$ ЦДІАК України. Ф. 442. Оп. 634. Спр. 654. Арк. 1-9.

${ }^{35}$ Skarzyński Z. Od specialnego delegata «Dziennik Kijowsk»i. Lysty z Humania. Dziennik Kijowski. 1906. № 127. 7 lipca. S. 2.

${ }^{36}$ ДАКО. Ф. 10. Оп. 1. Спр. 54, 61.

${ }^{37}$ ДАКО. Ф. 10. Оп. 1. Спр. 537.
} 
шкіл, 73\% з яких були розташовані в селах, з них по Київській губернії - 105 шкіл ${ }^{38}$.

31906 р. у с. Велика Чернявка Бердичівського повіту функціонувала таємна польська школа, в якій учні платити лише 1 руб. 50 коп. за весь зимовий період. Школа була відкрита 3 дозволу ксьондза Беліловської римо-католицької парафії ${ }^{39}$. 14 вересня 1906 р. за підтримки директора Пустоварівського цукрового заводу в с. Мала Сквирка Сквирського повіту було відкрито католицьку школу, де вчителькою була Ф. Кругликовська, а розпорядником - ксьондз м. Володарки ${ }^{40}$.

Після скасування указу від 3 квітня 1892 р. «Про покарання за таємне навчання у західних губерніях імперії» на території краю почали відкриватися без належного дозволу польські школи.

у 1907 р. в с. Пустоха Бердичівського повіту було відкрито польську школу в якій навчалося 20 учнів у віці від 10 до 14 років. Того ж року Б. Крачкевич відкрив польську школу в приміщенні костьолу, наданому ксьондзом А. Жолковським ${ }^{41}$.

У вересні 1907 р. дворянином В. Сляським було відкрито таємну школу у м. Бердичів. Викладалося читання, письмо та молитви для дітей римо-католицького віросповідання. Вчителькою зголосилася працювати на безоплатній основі дворянка А. Шостак ${ }^{42}$.

На початку жовтня 1907 р. під патронатом парафіяльного попечительства Володарського римо-католицького костелу було відкрито таємну польську школу, приміщення якої складалося 3 декількох кімнат (столярна майстерня та спальні для хлопців), які перебували на повному пансіоні. Викладалися арифметика, географія, російська та польська мови, Закон Божий, кошикове та столярне ремесла. Закладом опікувався місцевий ксьондз В. Шостаковський ${ }^{43}$.

Наприкінці 1907 р. за сприяння ксьондза Бончковського у с. Зарудинці Бердичівського повіту в будинку селянина М. Добржанського засновано польську школу, яку відвідували 21 хлопчик і 14 дівчаток. У ній викладався Закон Божий, польська мова та письмо. Крім дітей католицького віросповідання, школу відвідував православний хлопчик 3. Латко ${ }^{44}$.

17 грудня 1907 р. у Білій Церкві було виявлено дві польські школи, які були створені на пожертви римо-католицької громади. В одній школі викладали для хлопчиків, в іншій - для дівчаток. Закон Божий викладав настоятель Білоцерківської римо-католицької парафії ксьондз Лущек ${ }^{45}$.

У 1907-1908 рр. в Умані було організовано жіночу організацію «Уманське польське жіноче коло», метою якого було піднесення культурного, морального та економічного становища польського населення ${ }^{46}$. «Коло» мало на меті діяти як в Умані, так і на

\footnotetext{
${ }^{38}$ Zasztowt L. Polskie szkółki ludowe na Ukrainie w latach 1905-1914. Rozprawy z dziejów oświaty. 1990. T. XXXIII. S. 94.

39 ДАКО. Ф. 2. Оп. 75. Спр. 226. Арк. 1-3.

40 ДАКО. Ф. 2. Оп. 73. Спр. 282. Арк. 1-4.

${ }^{41}$ Іваненко О. Просвітницька діяльність поляків у Київській губернії на початку ХХ ст. Міжнародні зв'язки україни: наукові пошуки і знахідки. 2016. Вип. 25. С. 174.

42 ДАКО. Ф. 2. Оп. 73. Спр. 286. Арк. 6.

${ }^{43}$ ДАКО. Ф. 2. Оп. 73. Спр. 287. Арк. 9.

${ }_{44}^{44}$ ДАКО. Ф. 2. Оп. 73. Спр. 374. Арк. 4.

${ }^{45}$ ДАКО. Ф. 2. Оп. 73. Спр. 386. Арк. 1-3.

${ }^{46}$ ДАКО. Ф. 10. Оп. 1. Спр. 54.
} 
території всієї Київської губернії. Наголошувалося на ключових завданнях організації: піднесення освіти та виховання, підготовка дівчат до вимог суспільного життя та існуючих умов праці, моральна підтримка жінок тих, що мешкають у місті, так і тих, що мешкають у сільській місцевості, піднесення їх релігійних знань та інтелектуального рівня, боротьба з алкоголізмом тощо. Підкреслювалася важливість розвитку та підтримки медицини та благодійництва (аптек, лікарень, притулків, акушерської допомоги $)^{47}$. Згадуються Марія Лісовська, Станіслава Дашкевич-Чайковська, Софія Бобінська ${ }^{48}$. Можливо саме про цю організацію написала Надія Суровцова у своїх спогадах: «Життя польської інтелігенції було інтенсивне, але відбувалось воно конспіративно... По вулиці Садовій була крамничка всіляких жіночих оздоб... однієї дами, польки. Щось скидалося, ніби це було підприємство не на комерційних засадах... То було або «ідейне» феміністичне підприємство, або з якимись польськими національними підвалинами...» ${ }^{49}$.

На початку ХХ ст. в Умані діяло товариство поляків «Огніско», яке опікувалося розвитком польської культури й освіти: «Поляки трималися окремо. Вони мали власний польський клуб «Огніско», де не поляки не бували. Вони провадили освітню роботу серед жіноцтва - було жіноче поступове коло, була організація гарцерів, скаутів та напевне і політичні підпільні організації. Вони мали зв'язки з австрійськими поляками, їздили постійно на курорти в Закопане, до Варшави, до Кракова. Все це свідчило про високий культурний рівень уманських поляків, а одночасно про їх нехіть до не поляків і замкненість польського уманського кола» ${ }^{50}$. Польський історик Т. Епштейн у своєму дослідженні згадує польську організацію під назвою «Огніво» у Києві ${ }^{51}$, напевне, регіональні осередки в Київській губернії носили назву «Огніско». До речі, асоціація поляків Умані «Огніско» відродилася у 1995 р.

За сприяння Бенедикта Ліпковського, брата Серафіма, який брав активну участь у спортивному житті та гарцерському русі, при «Огніску» в Умані було збудовано спортивний павільйон з освітленням, на якому взимку заливали льодовий каток. Це була непересічна подія для Умані того періоду. Великою популярністю серед учнів та учениць користувалися вечори танців організовані у школі. Найпопулярнішим танцем була мазурка ${ }^{52}$.

у 1906-1909 рр. легально діяло польське товариство «Освята». Метою товариства було «розумове й моральне піднесення всіх верств польського суспільства, а головне поширення освіти рідною мовою». Діяльність організації, обмежена Київською губернією, передбачала заснування бібліотек, музеїв, читалень, книгарень, читання публічних лекцій, загальноосвітніх курсів, вистав, літературних і музичних вечорів, виставок, створення шкіл і притулків для дітей і дорослих, інших навчальних і благодійних закладів, оголошення конкурсів у галузі науки та літератури й нагородження їхніх

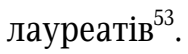

\footnotetext{
${ }^{47}$ ДАКО. Ф. 2. Оп. 228. Спр. 15. Т. II; Ustawa Koła Kobiet Polek w Humaniu. Kijow, 1908. S. 1-2.

${ }^{48}$ Ustawa Koła Kobiet Polek w Humaniu. Kijow, 1908. S. 14.

${ }^{49}$ Суровиова Н. Спогади. Київ: Вид-во ім. Олени Теліги, 1996. С. 26.

${ }^{50}$ Ibid. C. 28.

${ }^{51}$ Epsztein T. Edukacja dzieci i młodzieży w polskich rodzinach ziemiańskich na Wołyniu, Podolu i Ukrainie w II poł. XIX w. Warszawa, 1998. S. 29.

${ }^{52}$ Franciszek Strazalko (1904-1993). Srednia szkola polska w Humaniu 1917-1921. Pamietnik Kijowski. T. IV. S. 181-182.

${ }^{53}$ ЦДІАК України. Ф. 442. Оп. 636. Спр. 679. Арк. 11-16.
} 
Про товариство «Освіта» у дописі від 26 жовтня автор під псевдонімом Poraj повідомляв, що 8 жовтня відбулися перші загальні збори, на яких важливу роль відіграв А. Залютинський. Зазначалося, що загальний бюджет витрат на 1906-1907 pр. - 6400 руб. (польська школа в Умані, курси польської мови, придбання польських алфавітів, курси педагогічні, непередбачені витрати тощо). А у шкільному житті вже кинуто перші зерна любові до Вітчизни, і це надає позитивний імпульс для подвійної праці, обов'язкової в школі, так і тієї, що йде від поклику серця і крові, роботи над своєю польськістю. У касу товариства надійшло 2200 руб. Автор закликав кожного свідомого поляка Умані й околиць вступити до спільноти ${ }^{54}$

Активність польської еліти в освітній сфері та поразка революції 1905 р. змусила царську адміністрацію знову активізувати боротьбу проти польської освітньої діяльності. Так, 9 лютого 1911 р. київський генерал-губернатор Ф. Трепов оприлюднив постанову, яка передбачала покарання не лише для осіб, які безпосередньо брали учать у відкритті шкіл, а й тих, хто сприяв їх роботі, надавав приміщення й ін. ${ }^{55}$ Згідно закону «Про покарання за таємне навчання у західних губерніях імперії» від 1892 р. збільшувався розмір штрафу 3 300 до 500 руб. (або трьохмісячне ув'язнення) ${ }^{56}$.

у січні 1913 р. в с. Кулишівка Радомишльського повіту було викрито польську таємну школу. Міщанина П. Янишевського звинуватили у наданні приміщення під школу та посадили під арешт на один тиждень. А настоятель Коростишівського римокатолицького костелу, ксьондз І. Мацейський, керував школою й утримував вчителя К. Шачковського, за що отримав місяць арешту. Цього ж року у березні було викрито ще одну таємну школу в Умані, яка знаходилася у приміщенні настоятеля Уманського римокатолицького костелу, ксьондза В. Пржицького. На нього було накладено штраф у сумі 300 руб., у разі несплати покарання замінювалося на два місяці арешту ${ }^{57}$.

2 квітня 1913 р. Київський губернатор підписав постанову про арешт настоятеля римо-католицького костелу Вітольда Пржисецького за надання у своєму будинку приміщень для таємної польської школи ${ }^{58}$. Ця таємна польська школа відома була поліції під назвою «Християнська пральня» ${ }^{59}$. Перша таємна школа, яку було викрито у 1910 p. $^{60}$

Настоятель костелу ксьондз Вітольд Пржисецький був після смерті Карла Закусила головою «Уманського римо-католицького благодійницького товариства» (1913-1914) ${ }^{61}$. У 1915 р. в Умані функціонували одне Польське доброчинне товариство, один польський дитячий притулок, польський притулок для літніх людей ${ }^{62}$.

Чиновник Міністерства внутрішніх справ А. Зайончковський, якого направили до губернії для ліквідації польського шкільництва, вказував, що важливу роль у відкритті польських шкіл відігравали численні доброчинні організації, які організовували римо-

\footnotetext{
${ }^{54}$ Poraj. Pierwsze walne zebranie Tow. «Oswiaty» w Humaniu (Про товариство «Освіта»). Dziennik Kijowski. 1906. № 203. 13 (26) жовтня, S. 2-3.

${ }^{55}$ ЦДІАК України. Ф. 442. Оп. 861. Спр. 497. Арк. 12.

${ }^{56}$ Сейко Н. Польське шкільництво на Волині-Житомирщині у XIX - першій половині XX ст. Житомир, 2002. С. 76.

${ }^{57}$ ЦДІАК України. Ф. 274. Оп. 1. Спр. 3172. Арк. 2, 6.

${ }^{58}$ ЦДІАК України. Ф. 442. Оп. 861. Спр. 317.

${ }^{59}$ ЦДІАК України. Ф. 442. Оп. 861. Спр. 259.

${ }^{60}$ ЦДІАК України. Ф. 442. Оп. 860. Спр. 22; ЦДІАК України. Ф. 442. Оп. 861. Спр. 9.

${ }^{61}$ Календарь-справочник г. Умани и его окрестностей на 1914 год. Умань, 1913. С. 32.

${ }^{62}$ ДАКО. Ф. 2. Оп. 231. Спр. 608.
} 
католицька церква та польська еліта. Вихід із ситуації, що склалася 3 польським шкільництвом у Київському генерал-губернаторстві, він вбачав у посиленні роботи поліції, місцевих адміністрацій, а також в обмеженні польського просвітницького руху, фактичній забороні діяльності створених католицькими священиками, польською знаттю, доброчинних організацій ${ }^{63}$.

Таким чином, польський сегмент в освіті існував в умовах посилення русифікації, польсько-російського протистояння з метою перетворення Південно-Західного краю на невід'ємну складову російського простору. Польська школа 3 метою збереження національної самосвідомості поряд із законними засобами, застосовувала напівлегальні методи боротьби, що вилилися у формі таємних шкіл. Інтенсивність реалізації політики обмеження щодо польського шкільництва залежала як від ситуації у регіоні, так і від людей, які провадили цю політику. Певне послаблення мало місце під час революційних подій 1905-1907 рр., проте з поразкою революції утиски польської освіти відновилися.

Olha Honcharova, Igor Kryvosheia

\section{The activity of secret Polish schools in the Kyiv province (the last third of the XIX - early XX century)}

Abstract: The article deals with the analysis of the state of education of the Polish nobility of the Kyiv province under the conditions of russification and further integration of the Right-bank Ukraine into imperial structures in the last third of the XIX - at the beginning of the XX century. Repressive politics of tsarist government found confirmation in a number of laws and regulations, according to which teaching in Polish and speaking this language were forbidden, the access of Polish students to schools and universities was restricted.

Discriminatory politics of tsarism didn't lead to complete elimination of educational activities of Poles. However, Russian tsarism failed to completely eradicate the long-standing traditions of Polish schooling by official decrees and repressive measures. Russian tsarism made certain concessions in the sphere of education during the revolutionary events of 1905-1907, but it was not a long-lasting measure. Deprived of legal school activities, the Poles created secret schools and boarding houses, in which children of the declassed and legitimized nobility studied. Under these conditions home education, especially for women, became essential for the development of self-awareness, the process of the upbringing of children and youth.

During this period national education and upbringing were not only the main factor of resistance against the tsarist government, but also contributed to the preservation and formation of national consciousness of the Poles.

The role of the nobility and the Roman Catholic Church in the formation of Polish culture and education has been analyzed on the example of the Kyiv province. The creation of Polish secret schools and societies (a Polish club «Ognisko», Uman Roman Catholic Charitable Society, a society «Education», women's organization «Uman Polish Women's Circle», a secret school «Christian Laundry», etc.) and their significance in the preservation of national traditions have been considered.

Keywords: education, secret schools, Polish nobility, Kyiv province, integration politics, russification

${ }^{63}$ ЦДІАК України. Ф. 442. Оп. 861. Спр. 218. Арк. 37-72. 